\title{
Analysis of a low ozone episode over Extremadura (Spain) in January 2006 and its influence on UV radiation
}

\author{
M. Antón, M. L. Cancillo, A. Serrano, J. A. García, and F. J. Acero \\ Departamento de Física, Universidad de Extremadura, Badajoz, Spain
}

Received: 19 November 2007 - Revised: 27 February 2008 - Accepted: 25 March 2008 - Published: 7 April 2008

\begin{abstract}
The main objectives of this work are to analyze, firstly, the detail of the causes of a low ozone event which occurred in January 2006 and, secondly, the related effects of this anomalous episode on ultraviolet (UV) radiation measured at three locations in Extremadura (South-Western Spain). On 19 January 2006, the OMI total ozone column (TOC) was 16-20\% below the January mean value of TOMS/NASA TOC (period 1996-2005). The back trajectories analysis with the HYSplit model indicates that the notable decrease of TOC could be attributed to a fast rise of the isentropic trajectories height. Concomitantly, UV erythemal radiation greatly increases (between 23\% and 37\%) on 19 January 2006 respect to UV erythemal radiation measured on 19 January 2005. This notable increase in winter UV solar radiation may involve harmful effects for organisms adapted to receive less radiation during that season (e.g. early developmental stages of terrestrial plants and phytoplankton).
\end{abstract}

\section{Introduction}

During the last decades, events of extremely low ozone lasting two or three days have been reported in both hemispheres (Bojkov et al., 2001). This type of episodes are usually named ozone mini-holes (Newman et al., 1988) and they can be explained by different dynamic processes such as the displacement of the polar vortex (James et al., 2000), influence of planetary waves (Schoeberl et al., 1983), advection from the tropics of air patches with low total ozone content (Allart et al., 2000) or isentropic vertical uplift air-mass in the lower and middle stratosphere (Iwao et al., 2006). The ultraviolet (UV) radiation is strongly influenced by ozone due to absorption at wavelengths below $320 \mathrm{~nm}$. Therefore, the observed ozone mini-hole episodes are expected to have a notable influence on UV radiation values measured at the surface especially under clear skies (Austin et al., 1999; Stick et al., 2006).

Very few results about UV radiation analyses during ozone mini-hole episodes have been published to date in Spain (Córdoba et al., 2000; Antón et al., 2007). These studies have a great interest in this country, and particularly in the Extremadura region (South-Western Spain) due to the high UV radiation values measured at these latitudes throughout

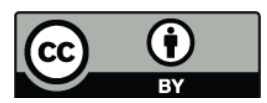

Correspondence to: M. Antón

(mananton@unex.es) the year (Serrano et al., 2006). In Extremadura, for cloudfree conditions the UV Index (UVI) varies between maximum values of 11 during summer and a minimum of about 1.5 in winter.

In this perspective, the present article analyzes the causes of an ozone mini-hole episode in Spain on 19 January 2006 and its influence on the UV radiation recorded in Extremadura. Therefore, this study will contribute to improve our knowledge about such extreme events, which produce a very short-term variability of TOC.

\section{Data}

We analysed the ozone mini-hole event using total ozone data provided by the OMI satellite instrument onboard EOS/Aura platform from July 2004. This satellite instrument is a contribution of the Netherlands's Agency for Aerospace Programs (NIVR) in collaboration with the Finnish Meteorological Institute (FMI). The OMI ozone data are available everyday of the year via anonymous ftp service (ftp://toms.gsfc.nasa.gov/ pub/omi/data/ozone/).

UV erythemal radiation in UV-index units, recorded by three Kipp \& Zonen broad-band radiometers, have been used to study the effects of the ozone mini-hole episode on UV radiation at the earth's surface. The three broad-band radiometers are located at Badajoz $\left(38.99^{\circ} \mathrm{N}, 7.01^{\circ} \mathrm{W}\right.$, altitude: $199 \mathrm{~m})$, Cáceres $\left(39.48^{\circ} \mathrm{N}, 6.34^{\circ} \mathrm{W}, 397 \mathrm{~m}\right)$ and Plasencia

Published by Copernicus Publications. 


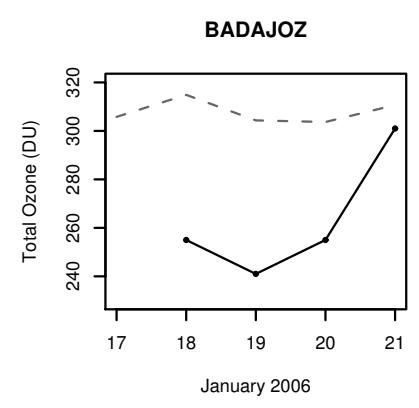

BADAJOZ

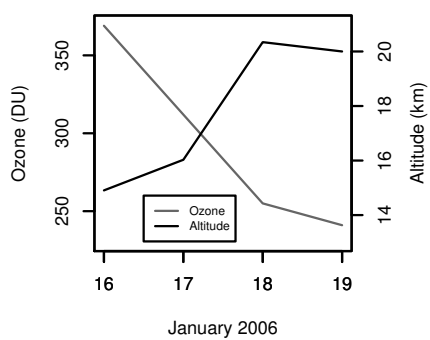

BADAJOZ

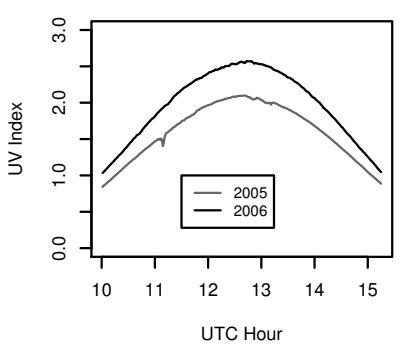

CÁCERES

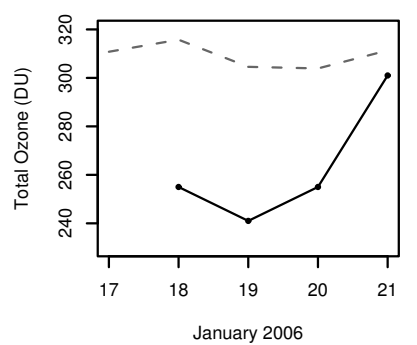

CÁCERES

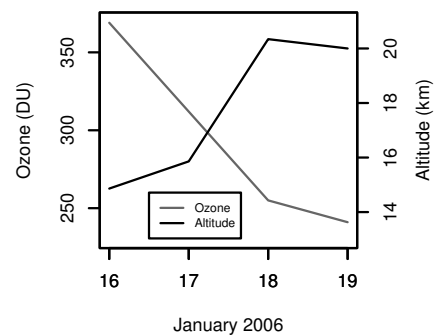

CÁCERES

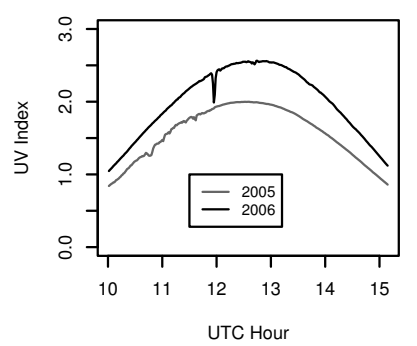

PLASENCIA

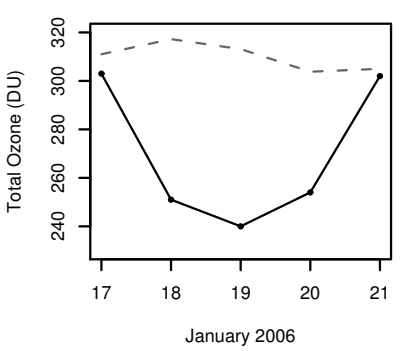

PLASENCIA

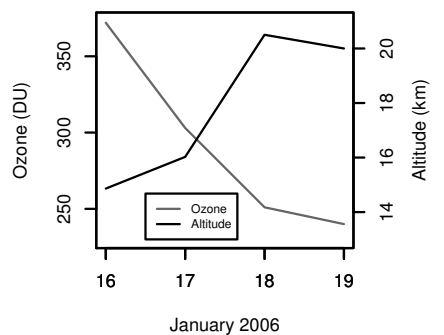

PLASENCIA

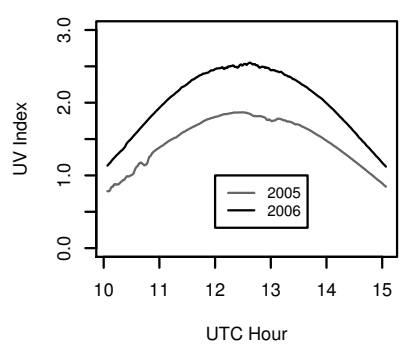

Figure 1. Temporal evolution of (top panel) total ozone measured by OMI from 17 to 21 January 2006 (the dashed line indicates the TOMS/NASA climatological mean value of January 1996-2005), (middle panel) total ozone amount and the air parcel altitude of three isentropic back-trajectories, and (bottom panel) the erythemal UV irradiances in units of UV-index measured on 19 January of years 2005 and 2006 in Badajoz, Cáceres and Plasencia.

$\left(40.06^{\circ} \mathrm{N}, 6.04^{\circ} \mathrm{W}, 372 \mathrm{~m}\right)$. These instruments have participated in three outdoor inter-calibration campaigns during the period 2001-2005 with a well-characterized and calibrated Brewer MK-III spectrophotometer, which belongs to the National Institute of Aerospace Technology (INTA) and it is located at El Arenosillo in Huelva, Spain $\left(37.1^{\circ} \mathrm{N}, 6.7^{\circ} \mathrm{W}\right.$, $20 \mathrm{~m}$ a.s.l.). These three campaigns show that the calibration factors of the broadband UV instruments present a negative trend attributable to instruments aging. Thus, a linear expression as a function of time was derived in order to calculate the calibration factors of each instrument (Antón, 2007).

To determine the origin of air mass, a trajectory analysis for the three locations was performed using the URL/UHHYSPLIT_4 model (HYbrid Single-Particle Lagrangian Integrated Trajectory version 4) of NOAA Air Resources Lab- oratory (ARL) with associated codes developed by the University of Houston (UH). More details of this model are given in Draxler and Hess (1997).

\section{Results and discussion}

The evolution of OMI TOC data during January 2006 shows low values on 18-20 January 2006 over the three Extremadura locations (Fig. 1, top), with a minimum on 19 January: 247 DU (Badajoz), 241 DU (Cáceres) and 240 DU (Plasencia). Thus, the TOC values were 16-20\% below the January mean value (period 1996-2005) obtained by the TOMS/NASA instrument. In addition, the mean TOC values ( \pm one standard deviation) in January 2006 were $(306 \pm 38)$ DU for Badajoz, $(304 \pm 36)$ DU for Cáceres and 
$(303 \pm 37)$ DU for Plasencia. It can be seen that these mean values are quite higher than the minimum TOC on 19 January (relative increase higher than 23\%). After 20 January, the total ozone amount returned to levels which can be considered as usual for these geographical locations and season. In order to understand the significance of the ozone mini-hole episode of 19 January 2006, TOC values were compared to these recorded by TOMS/NASA on 19 January 2005; 294 DU in Badajoz, 298 DU in Cáceres, and 299 DU in Plasencia.

A complete trajectory analysis with the HYSplit model on the $450 \mathrm{~K}$ isentropic surface from 15 to 19 January was performed for studying the origin and height of the air mass arriving at Extremadura. According to this trajectory analysis and OMI data, the low TOC values over the measuring sites can not be associated to the origin of air mass, which came from high latitudes with high TOC values. In contrast, Fig. 1 (middle panel) shows that the TOC values on 19 January 2006 practically coincide with a fast rise of isentropic trajectories (altitude increase of approximately $6 \mathrm{~km}$ ). The meteorological conditions on 19 January 2006 were examined in order to study the causes of this vertical displacement of air patches. It has been documented that ozone mini-hole episodes often occur during high pressure blocking conditions (Antón et al., 2007). Indeed, the analysis of the $1000 \mathrm{hPa}$ geopotential height field indicates the presence of the Azores high-pressure cell. Warm anticyclones intensify with high pressure, and air flowing on these surfaces could be forced to rise and expand. Therefore, the vertical displacement of air parcels affected TOC values by simply decreasing the pressure thickness of the ozone layer, without changing the mixing ratio.

UV erythemal radiation in units of UV-index (UVI) recorded at Badajoz, Cáceres and Plasencia, were used to study the effects of the low ozone episode on UV radiation. The ozone mini-hole event coincided with cloud-free conditions, which allowed an optimal analysis of the effects in UV radiation produced by the TOC decrease. Fig. 1 (bottom panel) shows that UVI values on 19 January 2006 were quite higher than UVI values measured on 19 January 2005 (this day also presented cloud-free conditions). On 19 January 2006, the mean UVI between 11:00 and 14:00 UTC was 23-37\% higher than the mean UVI for the same period on 19 January 2005. These anomalous high UVI values in January are usually recorded only about one month later, thus showing the significance of this low ozone episode. Since this anomalous event occurred in winter, the UV erythemal irradiance over a horizontal surface is relatively low compared to the irradiance during summer. However, this great increase in winter UV solar radiation may involve harmful effects for systems adapted to low seasonal radiation levels. For example, changes at an early stage of the growing phase may have diverse effects at later stages.

\section{Conclusions}

An unusual low ozone episode occurred over the Iberian Peninsula on 19 January 2006. We analysed this event over the region of Extremadura (South-western Spain) using OMI total ozone data and back trajectories analysis from HYSplit model. The ozone mini-hole episode was mainly due to a very fast adiabatic uplifting of the tropopause (vertical advection) above an upper tropospheric anticyclone in the hours previous to its arrival to Spain. The TOC values were more than $16 \%$ below the January mean values (period 19962005).

Measurements of the UV Index (UVI) at three locations in Extremadura were used to study the effects of an ozone minihole on UV radiation. The anomalous event coincided with cloudless conditions. Thus, on 19 January 2006, the UVI values were between $23 \%$ and $37 \%$ higher than UVI values measured on 19 January 2005. This important increase in winter UV solar radiation could involve adverse effects for organisms adapted to receive less radiation in that season.

Acknowledgements. This work has been partially supported by the "Ministerio de Educacion y Ciencia" under project CGL2005-05693-C03-03/CLI, by the "Junta de Extremadura" under "Convenio para la creación y mantenimiento de una red de medida de la radiación solar ultravioleta en Extremadura", and by the "Consejería de Infractucturas y Desarrollo Tecnológico" (GRU07126).

Edited by: S. Joffre

Reviewed by: two anonymous referees

\section{References}

Allart, M., Valks, P., Van der A, R., Piters, A., Kelder, H., and Van Velthoven, P.: Ozone mini-holes observed over Europe, influence of low stratospheric temperature on observations, Geophys. Res. Lett., 27, 4089-4092, 2000.

Antón, M.: Modelos empíricos para la estimación de la irradiancia solar ultravioleta, $\mathrm{Ph}$ Thesis, University of Extremadura, 2007.

Antón, M., Cancillo, M. L., Serrano, A., Vaquero, J. M., and García, J. A.: Ozone mini-hole over southwestern Spain during January 2004: Influence over ultraviolet radiation, Geophys. Res. Lett., 34, L10808, doi:10.1029/2007GL029689, 2007.

Austin, J., Driscoll, C. M. H., Farmer, S. F. G., and Molyneux, M. J.: Late spring ultraviolet levels over the United Kingdom and the link to ozone, Ann. Geophys., 17, 1199-1209, 1999, http://www.ann-geophys.net/17/1199/1999/.

Bojkov, R. D. and Balis, D. S.: Characteristics of episodes with extremely low ozone values in the northern middle latitudes 19572000, Ann. Geophys., 19, 797-807, 2001, http://www.ann-geophys.net/19/797/2001/.

Córdoba, C., Aguirre, I., Pérez, A., Sanz, A., Angulo, C., Vila, P., Monroy, E., Muñoz, E., and Jaque, F.: UV-B irradiance at Madrid during 1996, 1997 and 1998, J. Geophys. Res., 105, 4903-4906, 2000 . 
Draxler, R. R. and Hess, G. D.: Description of the HySplit_4 Modelling System, NOAA Technical Memorandum, ERL ARL-224, December, 24 pp., 1997.

Iwao, K.: Dynamical quantifications of ozone minihole formation in both hemispheres, J. Geophys. Res., 111, D02104, doi:10.1029/2005JD006333, 2006.

James, P. M., Peters, D., and Waugh, D. W.: Very low ozone episodes due to polar vortex displacement, Tellus B, 52, 11231137, 2000.

Newman, P. A., Lait, L. R, and Schoeberl, M. R.: The morphology and meteorology of southern hemisphere spring total ozone miniholes, Geophys. Res. Lett., 15, 923-926, 1988.
Schoeberl, M. R. and Krueger, A. J.: Medium scale disturbances in total ozone during southern hemisphere summer, B. Am. Meteorol. Soc., 64, 1358-1365, 1983.

Serrano, A., Antón, M., Cancillo, M. L., and Mateos, V. L.: Daily and annual variations of erythemal ultraviolet radiation in the South-western Spain, Ann. Geophys., 24, 427-441, 2006, http://www.ann-geophys.net/24/427/2006/.

Stick, C., Kruger, K., Schade, N. H., Sandmann, H., and Macke, A.: Episode of unusual high solar ultraviolet radiation over central Europe due to dynamical reduced total ozone in May 2005, Atmos. Chem. Phys., 6, 1771-1776, 2006, http://www.atmos-chem-phys.net/6/1771/2006/. 